\title{
A Philosopher in the Eye of the Storm: Monsieur Chouchani and Lévinas's "Nameless" \\ ESSAY \\ Hanoch Ben-Pazi
}

\begin{abstract}
This article considers the role of the individual during crises in humanism and the ethical responsibility with which the individual is charged in such times of moral calamity. In a narrow sense, the article explores Emmanuel Lévinas's "Nameless" ("Sans nom"), an essay that appears in his book Proper Names, and proposes viewing it as his personal reading in honor of his unique, unaccounted-for teacher Monsieur Chouchani. From a broader philosophical perspective, the article attempts to consider the meaning of ethics and the assumption of responsibility in times when doing so appears to offer no benefit and hold no significance whatsoever. From an educational perspective, it endeavors to better understand the ethical role of the teacher in both tranquil and tempestuous times. And finally, it also offers another profound observation of what Lévinas's article refers to as the "Jewish condition," not in a national historical sense but as a model of crisis-oriented ethical challenge.
\end{abstract}

\section{NAMELESS}

"Nameless," an essay written by Emmanuel Lévinas twenty-five years after the end of World War II, ${ }^{1}$ bears the emotional weight of life after the Holocaust and World War II, which Lévinas describes as "the unjustified privilege of having survived six million deaths," 2 and, equally as important, a traumatic sensitivity to the sense of an illness nesting at the heart of humanity-like a tumor remaining in our memory after the disruption of life itself. Can the return of life to its previous order - with its entertainment, its professional undertakings, and its leisure timebe deemed acceptable? Can the reemergence of literature, ethical writing, and institutions working in the defense of human rights manage to conceal the sense of deep chasm into which humanity has fallen? For those who lived through the Holocaust and World War II, maintains Lévinas, "nothing has been able to fill, or even cover over, the gaping pit."3

But what are we to pass on to our children who were born immediately following liberation? Are we obligated to imbue them with the same unsteadiness from which we ourselves suffer, to the point of a sense of deep illness stemming from our personal memories from that period? Although there are certainly

1. Emmanuel Lévinas, "Nameless," in Proper Names, trans. Michael B. Smith (Stanford, CA: Stanford University Press, 1996), 119-23.

2. Ibid., 120.

3. Ibid. 


\section{Hanoch Ben-Pazi}

emotions that we cannot convey to our children, acknowledges Lévinas, there are many things that we can and must pass down. ${ }^{4}$ After all, even after the end of the war, humanity continues to live with far too much evil:

Since the end of the war, bloodshed has not ceased. Racism, imperialism and exploitation remain ruthless. Nations and individuals expose one another to hatred and contempt, fearing destitution and destruction.

But at least the victims know whither to lift their dying gaze. Their devastated areas belong to a world. Once again undisputed opinion, undisputable institutions and Justice exist. In discussion, in writing, in the schools, good has rejoined the Good of all latitudes, and evil has become the Evil of all time. Violence no longer dares speak its names. What was unique between 1940 and 1945 was the abandonment. One always dies alone, and everywhere the hapless know despair. And among the hapless and forlorn, the victims of injustice are everywhere and always the most hapless and forlorn. But who will say the loneliness of the victims who died in a world put in question by Hitler's triumphs, in which lies were not even necessary to Evil, certain of its excellence? Who will say the loneliness of those who thought themselves dying at the same time as Justice, at a time when judgments between good and evil found no criterion but in the hidden recesses of subjective conscience, no sign from without? ${ }^{5}$

Lévinas's essay "Nameless" was originally published in the journal Les nouveaux cahiers under the title "Honneur sans drapeau" (Honor without flag) ${ }^{6}$ — and only

4. On the meaning and treatment of the concept of education in Lévinas's writings, the reader is first encouraged to consult the following article by Annette Aronowicz: "L'éducation juive dans la pensée d'Emmanuel Lévinas," Pardès 26 (1999): 195-210; or in English, "Jewish Education in the Thought of Emmanuel Lévinas," in Abiding Challenges: Research Perspectives on Jewish Education; Studies in Memory of Mordechai Bar-Lev, ed. Yisrael Rich and Michael Rosenak (London: Freund, 1999), 65-100. See also Ami Bouganim, "Lévinas pedagogue," in Emmanuel Lévinas-Philosophe et pédagogue (Paris: Éditions du Nadir, 1998), 55-64; Catherine Chalier, "Lévinas maître," in Emmanuel Lévinas-Philosophe et pédagogue, 65-70; Paul Standish, "Ethics before Equality: Moral Education after Lévinas," Journal of Moral Education 30 (2001): 339-47; Mark Child et al., “Autonomy or Heteronomy? Lévinas's Challenge to Modernism and Postmodernism," Educational Theory 45 (1995): 167-89. Much has been written on the importance and responsibility of education in the writings of Lévinas. See for example: Hanoch Ben-Pazi, "Rebuilding the Feminine in Lévinas's Talmudic Readings," Journal of Jewish Thought and Philosophy 12, no. 3 (2003): 1-32; Ben-Pazi, "Establishing the Future: Educational Meanings of Revelation and the Messianic Idea according to Lévinas" [in Hebrew], Hagut-Jewish Educational Thought 5-6 (2004): 89-114; Chalier, "Lévinas maître"; Claire Elise Katz, "Teaching the Other: Lévinas, Rousseau, and the Question of Education," Philosophy Today 49 (2005): 200-207; Katz, "Educating the Solitary Man: Lévinas, Rousseau, and the Return to Jewish Wisdom," Lévinas Studies 2 (2007): 133-52; Katz, Lévinas and the Crisis of Humanism (Bloomington: Indiana University Press, 2012); Ephraim Meir, "Jewish Dialogic Philosophy and Its Implications for Education" [in Hebrew], Hagut_Jewish Educational Thought 1 (1998): 127-41; Birgit Nordtug, "The Welcoming of Lévinas in the Philosophy of Education-At the Cost of the Other?," Theory and Research in Education 11 (2013): 250-68.

5. Lévinas, "Nameless," 119.

6. Emmanuel Lévinas, "Honneur sans drapeau," Les nouveaux cahiers 6 (1966). 
later found its way into Proper Names, a collection of essays dealing with important figures such as Shmuel Yosef Agnon, Edmond Jabes, and Paul Celan. The book's final three essays are devoted to World War II: the first to Father Herman Leo Van Breda, who in 1938 continued to believe in reason and helped safeguard Husserl's manuscripts, ${ }^{7}$ and the second to Jean Wahl, who established the philosophical club in Paris after the war and whose unique obligation to humanism and feeling transcended any philosophical system Lévinas attempted to highlight. ${ }^{8}$ The third is the essay under discussion here: "Sans nom"- "Nameless." Despite Lévinas's decision to change the essay's name to "Nameless" when including it in Proper Names, I posit that this text does indeed have a name and a very special name at that, specifically, that of a peculiar individual whose real name we do not know, but to whom Lévinas and others have referred as M. Chouchani: Lévinas's teacher of talmudic reading and interpretation. The name itself is a pseudonym. ${ }^{9}$ In the essay, Lévinas refers to his "frequent visits to M. Chouchani, the prestigious - and merciless - teacher of exegesis and of Talmud." 10

The many attempts that have been made to tell the story of this unique man have included fascinating attempts to determine his real name. Some of the betterknown students of Chouchani included Professor Shalom Rosenberg, who identified him as Hillel Perlmann, finding reference to him under this name as a unique and exceptionally skilled student of Rabbi Abraham Isaac Kook. ${ }^{11}$ Elie Wiesel, on the other hand, maintains that Chouchani's real name was Mordechai Rosenbaum, a name that he subsequently changed to Mordechai Ben-Shushan, and offers biographical and narrative support for his claim. ${ }^{12}$ The purpose of this article, however, is not to shed light on the character, personality, or real name of

7. Lévinas, "Nameless," 106-9.

8. Ibid., 110-18.

9. Although the mysterious Monsieur Chouchani has been the subject of numerous texts, the riddle remains. On this, see first and foremost Salamon Malka, Monsieur Chouchani: l'énigme d'un maître du XXe siècle: entretiens avec Elie Wiesel, suivis d'une enquête (Paris: JC Lattès, 1994); Marie-Anne Lescourret, Emmanuel Lévinas (Paris: Flammarion, 1994), 142-45; François Poirié, Emmanel Lévinas: Qui êtes vous? (Lyon: La Manufacture, 1987), 125-30; Shmuel Wygoda, "Le maître et son disciple: Chouchani et Lévinas," Cahiers d'etudes Lévinassiennes 1 (2002): 149-83. See also Zev Harvey, "Chouchani on the Prophecy of Moshe Rabbeinu" [in Hebrew], in The Paths of Peace: Studies in Jewish Thought Presented to Shalom Rosenberg, ed. Benjamin Ish-Shalom and Amihai Berholts (Jerusalem: Beit Morashah, 2007), 459-65, and see also the sources in notes 1-2 and 14; Masha Turner, "One Evening with M. Chouchani: An Act That Occurred" [in Hebrew], in IshShalom and Berholts, Paths of Peace, 467-68.

10. Emmanuel Lévinas, "Signature," in Difficult Freedom: Essays on Judaism, trans. Seán Hand (Baltimore, MD: Johns Hopkins University Press, 1990), 291.

11. On Chouchani's identification as Hillel Perlmann, see the editorial (apparently by Moshe Nachmani), "Great Insights on the Mysterious Genius R. Hillel Perlmann: M. Chouchani, a Student of R. Abraham Isaac Kook" [in Hebrew], 'Or hadash 15 (2011): 6-17; Yoav Sorek and Uri Paz, "The Sting of the Giant of Knowledge: On Mr. Chouchani," an interview with Prof. Shalom Rosenberg on Monsieur Chouchani [in Hebrew], Hagut yehudit (Rosenberg's website for Jewish thought) http:// hagut.org/h/index.php/2014-01-21-19-12-18/36-6724.

12. Elie Wiesel is the source of the unique inscription on Chouchani's gravestone in Montevideo: "The wise Rabbi Chouchani of blessed memory. His birth and his life are sealed in enigma." 


\title{
Hanoch Ben-Pazi
}

M. Chouchani. In fact, in a certain sense, our inability to determine Chouchani's real name serves to validate our attempt to associate the specific - "nameless"essay under discussion here with this teacher. The true essence of our discussion concerns the manner in which Lévinas portrays Chouchani's character and what we stand to learn from it, not only in terms of his method of talmudic instruction but also in terms of his spirit as an educator of extraordinary virtue.

For our part, we can view Chouchani as a great teacher of ethics: not a philosopher who teaches the concepts of the field but rather a man who teaches ethics in a wholly unique manner-through his own stormy life during a tempest. Chouchani was not one to keep good to himself but rather a man who entered the eye of the storm in times of crisis. In this context, Lévinas references Mikhail Lermontov's "The Hero of Our Generation," 13 characterizing the aim of ethics in tempestuous times as not preserving the good but looking into the whirlwind in which there is no shelter:

\begin{abstract}
When the temples are standing, the flags flying atop the palaces and the magistrates donning their sashes, the tempests raging in individual heads do not pose the threat of shipwreck. They are perhaps but the waves stirred by the winds of the world around well-anchored souls within their harbors. The true inner life is not a pious or revolutionary thought that comes to us in a stable world, but the obligation to lodge the whole of humankind in the shelter - exposed to all the winds - of conscience. And, truly, it is mad to seek out the tempest for its own sake, as if "in the tempest rest resided" (Lermontov). But the fact that settled, established humanity can at any moment be exposed to the dangerous situation of its morality residing entirely in its "heart of hearts," its dignity completely at the mercy of a subjective voice, no longer reflected or confirmed by any objective order-that is the risk upon which the honor of humankind depends. But it may be this risk that is signified by the very fact that the Jewish condition is constituted within humanity. Judaism is humanity on the brink of morality without institutions. ${ }^{14}$
\end{abstract}

Beyond its unique poetics, Lévinas's essay also contains a number of formative principles of Lévinasian philosophy, such as the precedence of ethics over metaphysics and theology of any kind; the quest for universal meaning that can be derived from the Jewish sources; and the inquiry into ethical questions and action in times of historical sociopolitical disintegration and the defense of law and institutions. This description of the actions taken in tempestuous and chaotic times of destruction stands at the heart of the teacher's ethical work in

13. This is a reference to Mikhail Lermontov's "The Sail":

The sail is whitening alone / In blue obscurity of sea:

What did it leave in country own? / What does it want so far to see.

The wind is strong, the mast is creaking, / The wave is playing with the wave ...

But not a fortune is it seeking, / Nor from this fortune is its way.

By it a stream is bright as azure, / By beams of sun it's warmed and blessed

But it is seeking gales as treasure, / As if the tempests give a rest.

14. Lévinas, "Nameless," 122. 
society at the end of the twentieth century. The mode of educational activity is derived from the strength of the teacher's inner life and manifests itself in his or her ability to arouse students and others to their ethical lives. A teacher's work is work in times of crisis; it is the willingness to enter into the eye of the storm for the purpose of taking responsibility. ${ }^{15}$

\section{The Ethical Responsibility of the Teacher: The Willingness to Enter INTO THE EyE OF THE STORM}

Attention to several unique contexts in which Lévinas refers to his former teacher can provide insight into Chouchani's character as Lévinas depicted him in his writing, especially as expressed in "Nameless." In these contexts, we take note of Chouchani's isolation and solitude as someone assuming responsibility in a time of crisis; of his willingness to enter the storm itself; and of his role, as a teacher, in awakening and provoking thought in his students.

First we consider the manner in which Lévinas conceives of the role of the teacher in general, and, in the process, we take stock of this teacher: M. Chouchani. This vantage point also provides us with insight into Lévinas himself in his capacity as a "teacher," 16 both in the concrete sense of Lévinas as a classroom teacher and in the deeper sense of Lévinas not only as an individual whose thought and written philosophy expresses his internal need or desire to conduct an inquiry into or find the truth, but also as a philosopher whose philosophy is intended for the listener and the reader. ${ }^{17}$ This approach, which I regard as extremely important, requires the investigator to consider, in the case of each of Lévinas's philosophical texts, the intended recipient of his writing, and in this sense to distinguish and differentiate between the intended recipient of his meticulous philosophical writing and that of talmudic writing. ${ }^{18}$ In this context, it is preferable to question the straightforward, simplistic answer that maintains that talmudic writing was intended for the Jewish community, whereas philosophical writing is intended for the philosophical community.

A teacher's philosophy is a philosophy that assumes responsibility for what it thinks or says. It is a philosophy of ethics. We can now consider the fundamental academic right and duty to disconnect the subject matter of a philosophical inquiry

15. See Annette Aronowicz's work on the meaning of education in Lévinasian philosophy: "L'éducation juive dans la pensée d'Emmanuel Lévinas," and, in English, "Jewish Education in the Thought of Emmanuel Lévinas." See also Bouganim, "Lévinas pédagogue"; Chalier, "Lévinas maître"; Standish, "Ethics before Equality"; Child et al., "Autonomy or Heteronomy?"

16. This approach was first suggested to me by Jacques Rolland, one of Lévinas's closest students during a private conversation that took place in 2000 during a period of research in Paris. Rolland passed away due to illness in September 2002.

17. In this context, Rolland regarded Lévinas as someone who was guided by the figure of Maimonides and someone whose written philosophy appears first as a philosophy of teaching.

18. On the meaning of the discussion of Lévinas's intended philosophical recipient, see Annette Aronowicz's introduction to her English translation of the Nine Talmudic Readings. Emmanuel Lévinas, Nine Talmudic Readings, trans. Annette Aronowicz (Bloomington: Indiana University Press, 1990), ix-xxxix. 


\section{Hanoch Ben-Pazi}

and the person engaged in its creation. In this sense, the teacher is the creator who dares to enter the ethical storm at the precise location at which he or she is needed and the person who takes responsibility where others dare not do so. The teacher is always found at the midpoint, the transition between worlds, in that he or she takes responsibility for the future - for the world we will receive - and opens up new worlds before us.

Thinking of Lévinas the philosopher as a teacher allows us to focus our attention on the ethical purpose of education. The educational act itself has a dimension of ethical training but also constitutes an ethical event that is itself worthy of philosophical inquiry. It is not only a case of a teacher preparing the student for life as an adult; it is also an arena of ethical challenge for the teacher, who must view the student as an Other whose alterity he or she is obligated to respect. It is an obligation of the teacher, of his or her present and present position (in both senses of the word) vis-à-vis that which he does not know-vis-à-vis the future. From Lévinas's perspective, it is the educational event that creates the future, based on its situation in the present and its orientation toward the future. ${ }^{19}$ It is an ethical orientation vis-à-vis the Other because it opens up the present, out of its totality, to new places and possibilities it has yet to know, and at the same time takes responsibility for this openness. The teacher seeks not to shape the student in his image, as this lacks the educational dimension of the future and instead constitutes a return to the past. Instead, he is obligated to engage in the weighty ethical effort of opening himself up to an unknown future and enabling his students to continue moving forward beyond it, in the words of Lévinas, to infinity.

From Lévinas's perspective, the deeper meaning of education is reflected in its major role in establishing the community, which he refers to as a "pact" in the sense of a social contract. This pact in Judaism is not established through a one-time divine revelation between god or prophet and man. It is, rather, the product of recurring revelation through the simple, everyday context of study and discussion between a teacher and his students, throughout the generations. This, according to Lévinas, explains the centrality of the "tent of assembly" ('ohel mo 'ed), not in the sense of a ceremonial tent or a tent in which Moses's divine revelation occurs but as the actual school of Moses. ${ }^{20}$ Focusing our attention on the tent of assembly as a school, as the place of study in which Moses taught, also sheds light on the major importance ascribed to education in the writings of the sages. Moses is a man of many qualities, including his designation as "a

man of God." ${ }^{21}$ But the designation most frequently assigned to him is Moshe

19. Hanoch Ben-Pazi, "Establishing the Future: Educational Meanings of Revelation and the Messianic Idea according to Levinas" [in Hebrew], Hagut-Jewish Educational Thought 5-6 (2004): 89-114.

20. An extremely similar description of the importance of the teacher in the establishment of the Jewish pact is found in Rabbi Joseph Soloveitchik's article "The Community," Tradition 17, no. 2 (Spring 1978): 7-24.

21. Deuteronomy 33:1. 
Rabbenu- -Moses our Teacher." ${ }^{22}$ In many senses, Moses can be regarded as a model of a teacher who actualizes Lévinasian educational thought.

\section{Teaching the Stuttering Child-Education without Eloquence}

Here we must note the nuances in Lévinas's description of Moses, as the Moses he portrays as an exemplary figure in Jewish tradition is not a wellorganized teacher with eloquent speech and sophisticated manners. Moses, to whom Jewish tradition since the sages of the Mishnah and the Talmud have referred as Moses our Teacher-a phrase favored over Moses the Prophet and Moses "man of God"-is, first and foremost, Moses the stutterer. ${ }^{23}$ Lévinas uses Moses's image as a teacher to explore various dimensions of teaching, and one of the most prominent elements of this attempt at philosophical reflection on the role of Moses as a teacher, certainly from a modern perspective, is its emphasis on his difficulty in the realm of speech. Whether he stuttered or whether other speech problems hampered his ability to communicate, he is described as "slow of speech," "of a slow tongue," and "not eloquent," 24 indicating that his rhetorical abilities in the Greek sense of the word were not his best quality. Perhaps, as stressed by Lévinas, the exemplary figure of this teacher already tells us something about what he is not-he does not engage in "promotion" and does not take part in consumerist competition, and his status as a teacher is not determined by flattery of his students, their parents, or the surroundings. Indeed, the opposite appears to be true: "Strangely enough, Jewish wisdom maintains that style of its master, Moses, who was 'slow of speech and slow of tongue.' It is not a personal defect which perpetuates itself. It is the objective style of a thought which fails to embrace the forms of rhetoric. It is the way inspiration inspires in contact with harsh and complex and contradictory realities. A sermon without eloquence." 25

As far as Lévinas is concerned, we learn the meaning of the lack of rhetorical skill or "eloquence" from the realm of rhetoric. However, talmudic thought, he explains, is cautious of all rhetoric and maintains a standing suspicion and fear of eloquence, ${ }^{26}$ which appears to be grounded in the space that Lévinas dedicates

22. On Moses's role as a teacher in Jewish thought, see André Neher, Moses and the Vocation of the Jewish People, trans. Irene Marinoff (New York: Harper Torchbooks, 1959); Martin Buber, Moses: The Revelation and the Covenant (Amherst, NY: Prometheus, 1988).

23. The phrase "the stuttering child" is borrowed from Ronny Someck's poem "Revenge of the Stuttering Child," which is devoted to Moses.

24. Exodus 4:10.

25. Lévinas, "Damages due to Fire," in Nine Talmudic Readings, 181. Emphasis mine.

26. Lévinas addresses the meaning of rhetoric separately from the meaning of eloquence. See "Langage quotidien et rhéthorique sans eloquence," in Hors sujet (1987; Paris: Le livre de poche, 1997), 183-94. In English, see "Everyday Language and Rhetoric without Eloquence," in Outside the Subject, trans. Michael Smith (Stanford, CA: Stanford University Press, 1994), 135-43. Rhetoric as a special type of teaching that either does or does not reflect honesty was already discussed by ancient philosophy. See Aristotle, Rhetoric, trans. W. Rhys Roberts (Mineola, NY: Dover, 2004) and Chaim Perelman, The Realm of Rhetoric, trans. William Kluback (Notre Dame, IN: University of Notre Dame Press, 2008). 


\section{Hanoch Ben-Pazi}

to the respect of the alterity of the Other. What is the motivation behind rhetoric and eloquent speech? Rhetoric and eloquence is a sometimes manipulative attempt to use language to make the Other identical to us, to make him belong to the "I" or "we." Eloquence does not prioritize respect for the alterity of the Other and uses speech in an effort to insert the Other into the language of the I. Indeed, what does the person using rhetorical language to the point of demagogy seek if not the not-entirely honest persuasion of an Other? The element of falsification is an integral part of eloquent language, and it is this dimension that is suspicious in the eyes of the Talmud.

These ideas are relevant to the model of M. Chouchani as a private teacher who, according to Lévinas, guided him to a deep understanding of the philosophical importance of talmudic wisdom and who was certainly not the epitome of eloquence and high rhetoric, but rather primarily a teacher of questions - the kind of teacher who knows no rest and demands the deepest and truest answers his students can provide. If education involves facing the Other in an honest manner or an openness to that which the student brings with him in his alterity, then eloquent speaking or teaching can actually hinder the teacher from fulfilling his or her purpose.

\section{The Insanity of Bearing Responsibility in a World Devoid OF ETHICALITY}

The second attribute we consider here is the ability to bear the impossible burden of responsibility that lies with the teacher. With regard to this issue, Lévinas also appears to be thinking of two legendary teachers: Moses and M. Chouchani. This proximity finds expression within one of Lévinas's wellknown texts, in which he describes the burden of responsibility for humanity that is sometimes borne by one man. Moses is the biblical figure who, for a certain time, bears the full weight of human responsibility in its entirety. ${ }^{27}$ This fascinating comparison offers considerable insight into Lévinas's instructional and educational motivation: whereas Moses is not only a teacher but also the "father of the nations" and the "master of the prophets," Chouchani never assumed the burden of public leadership. Nonetheless, Chouchani, like other people, bore major responsibility vis-à-vis the world as a whole, which is somewhat paradoxical, as Chouchani was Lévinas's teacher of talmudic wisdom, not of the universal context of humanity. Lévinas's consistent approach, however, holds that the meaning of Jewish wisdom should be expanded into its universal horizons.

In the context of the present discussion, Lévinas assigns universal ethical significance to the talmudic term "Israel" and regards it as corresponding to the broader concept of humanity, of being "a human being," and of acting in

27. In the talmudic reading "The Temptation of Temptation," Lévinas explains that the burden of the world sometimes falls on the shoulders of one man. The talmudic example of this dynamic is Moses, but Lévinas links this idea to the figure of his teacher Monsieur Chouchani. See "The Temptation of Temptation," in Nine Talmudic Readings, 30-50. 
accordance with humanity. "It is a recognition," he writes, "of the ultimate value of the human message borne by Judaism...."28 This idea, explains Lévinas, he learned from his distinguished teacher M. Chouchani. On this basis, Rabbi Akiva's words in the Mishnah Avot, "you are called man," can be interpreted not in a negative sense but rather as a positive statement regarding the universal message of Judaism. According to the terminology of Jewish wisdom, a man who acts ethically and responsibly is "Israel," or, in other words, "man." This unique interpretation is accepted by Lévinas by virtue of the authority it is ascribed:

We are not in the presence of a racist idea here. I have it from an eminent master: each time Israel is mentioned in the Talmud one is certainly free to understand by it a particular ethnic group which is probably fulfilling an incomparable destiny. But to interpret in this manner would be to reduce the general principle in the idea enunciated in the Talmudic passage, to forget that Israel means a people who received the Law and, as a result, a human nature which has reached the fullness of its responsibilities and its selfconsciousness. The descendants of Abraham, Isaac and Jacob are human beings who are no longer childlike. Before a self-conscious humanity, no longer in need of being educated, our duties are limitless. ${ }^{29}$

According to Lévinas, interpreting the term "Israel" as a reference to the Jewish people alone means reducing its true ethical significance. The Jews are a symbol of humanity, precisely because of their low standing in history and the persecution they have endured: “ $\ldots$ as if the notion of Israel, people of the Torah, people as old as the world and as old as persecuted mankind carried within itself a universality higher than that of a class exploited and struggling, as if the violence of the struggle were already alienation." 30

Lévinas's talmudic reading "The Temptation of Temptation," which focuses on the revelation at Mt. Sinai, provides context for discussion of the individual's responsibility for the world. The interpretation proposed by Lévinas shifts the emphasis of revelation from its religious theological sense to the ethical responsibility assumed by the individual. The Jewish people's willingness to accept revelation at Mount Sinai is a willingness, which precedes the commandment itself, to be responsible for other people and for society as a whole. He who assumes responsibility is rewarded for his grandeur by two crowns: "we shall do" and "we shall hear," one for each action. This responsibility is not theoretical but

28. Lévinas, "The Nations and the Presence of Israel," in In the Time of the Nations, trans. Michael B. Smith (Bloomington: Indiana University Press, 1994), 97. In the Talmud, the term "Israel" is understood as referring to universal content. "Precisely the opposite of what is typically said. The Talmud transcends the historical events of Israel, or at least expands them within the universal" (taken from the discussion following Lévinas's lecture about messianism). See "La conscience juive," in Données et débats (Paris: Presses Universitaires de France, 1963), 228. See also Jacques Rolland, "Quelques propositions certaines et incertaines," Pardès 26 (1999): 174-75.

29. Lévinas, "Judaism and the Revolution," in Nine Talmudic Readings, 98.

30. Ibid. 


\section{Hanoch Ben-Pazi}

rather gives expression to man's attentiveness to the existence and needs of others. Lévinas's reading leads him not to explore issues of the Jewish religion or Jewish culture but rather issues concerning people who, in practice, face questions of ethics. However, as we have seen, the true test of ethicality, and the true test of the teacher, comes in times of crisis. "The masters of the Talmud foresaw the situation," maintains Lévinas. "They find it serious but not desperate. Judaism has not lost its radiance because, for a time, it happens to live only in a few consciences." ${ }^{31}$

But although according to Lévinasian ethical doctrine a crisis does indeed represent failure, it does not override the fundamental willingness to accept the ethical imperative. Therefore, within the framework of a discussion on ethical responsiveness, the talmudic sugya identifies the golden calf as a reason why the crowns were taken from the Jewish people, but not as a reason for the relief of ethical responsibility. ${ }^{32}$ After all, even during the crisis itself, there was always someone who continued bearing the responsibility for good and for ethicality. According to the biblical narrative, this role was played by Moses. There are times, explains Lévinas, at which all good is the responsibility of one man. And as scholars and commentators on Lévinas have emphasized, this is a reference to Chouchani:

The text may be speaking to us of those times in which Judaism is practiced or studied only by a tiny minority, perhaps by only one man, when it seems to be completely contained in treatises, immobilized between book binding, and when living Jews have lost all influence as Jews. The text affirms, without, alas, proving it, that even in those conditions, Judaism has not lost all its luster. Moses, even if he loses his kingdom, remains a crowned king.... the masters of the Talmud foresaw the situation. They find it serious but not desperate. Judaism has not lost its radiance because, for a time, it happens to live only in a few consciences or to have gone back into the books that transmit it, like Moses's mind withdrawn to his tent. ${ }^{33}$

31. Lévinas, "Temptation of Temptation," 44.

32. Lévinas's words here refer to two types of responsiveness and sin: that which stem from the tempting nature of being tempted and that which stem from the temptation itself. Ethical responsiveness stems from a willingness to do good, in general, and is not extinguished by practical failure: "Sin itself does not destroy Temimut, the integrity which expresses itself in the 'We will do' preceding the 'We will hear.' The sin here responds to temptation but is not tempted by temptation: it does not question the certainty of good and evil. It remains an unadorned sin, ignorant of the triumph attained by faults liberated from scruples and remorse. Thus a path back is available to the sinner. The adherence to the good of those who said 'We will do and we will hear' is not the result of a choice between good and evil. It comes before it. Evil can undermine this unconditional adherence to the good without destroying it. This adherence is incompatible with any position beyond or above the good, whether it be the immoralism of esthetes or the supra-moralism of the religious, all that moral extraterritoriality opened up by the temptation of temptation." Lévinas, "Temptation of Temptation," 43.

33. Lévinas, "Temptation of Temptation," 44. Emphasis mine. 
Lévinas's account explores the serious states of crisis in which the world appears to have lost a fundamental commitment to good, and in which society appears to not be situated in a world that contains good and evil. In such instances, the burden of bearing the concepts of good and evil falls on the individual. Lévinas was apparently thinking of the days of World War II, when, as he explains, the concepts of "good" and "evil" were unclear. Such times, in which people think according to concepts of good and evil, lack ethicality. The task of the individual in such times is to continue personally bearing responsibility. This talmudic description speaks of a withdrawal of sorts into the tent, perhaps into the room of study or the library. Who plays the role of Moses during the difficult times discussed by Lévinas? Who recognizes the need to continue teaching and bears the burden of doing so?

\section{Phenomenal Memory - and Responsibility "Beyond Memory"}

If the model of Moses is one of withdrawal, Lévinas offers another model: one of taking complete responsibility and entering into the eye of the storm. He proposes this model by means of a secondary character in Vasily Grossman's Life and Fate, an inarticulate farmer named Ikonnikov. " "Grossman, who died in 1964," writes Lévinas, "was an assimilated Russian Jew, to whom Pushkin or even Nekrasov were, since childhood, necessary for the inner life - as they had already been to his mother. This Soviet writer certainly believed, in October of 1917, that he had entered into the times of eschatological events, so to speak. His work prior to Life and Fate expressed that hope and that faith with talent and sincerity. ${ }^{35}$ The question raised by Lévinas pertains to this responsibility for good in a world that has forgotten what good is, as in times of war. What must a person do in times of crisis and what is the significance of remembering such times?

The answer to this question, according to Lévinas, lies "beyond memory." 36 The memory of the Holocaust forces man to face the future, as the meaning of remembering the past lies in man's ability to take responsibility for the future. Lévinas describes the uninhabitable world depicted in Grossman's Life and Fate as "a dehumanized humanity ... a humanity transformed into camps in which the ' $I$ ' is no longer sure of its identity" ${ }^{37}$ - a universe that is desperate for humanity and humaneness. In the chaos of being without ethics, hope arises from the people who insist on the impossible. In the apocalypse of de-humanism, then, we find "indomitable humanity," which, within a world devoid of meaning, nevertheless offers a possibility of significance - to guarantee the foundation of the world. "That private goodness of an individual for another individual is a goodness without witnesses, a little goodness without ideology. It could be called goodness without thought. The goodness of men outside the religious or

34. Lévinas, "Beyond Memory," in In the Time of the Nations, trans. Michael B. Smith (Bloomington: Indiana University Press, 1994), 88.

35. Ibid.

36. Ibid., 76-91.

37. Ibid., 89. 
social good.... The history of man is the struggle of evil trying to crush the tiny seed of humanity. But if even now the human has not been killed in man, evil will never prevail. ${ }^{\text {3 }} 8$

Lévinas describes this position as naïve, using the metaphor of extinguishing the fire of the world with a syringe. Is there any meaning to kindness and goodness in a world without justice? Lévinas answer positively, by depicting the Exodus not as a historical event but as the ethical option for returning ethicality to a world that has forgotten ethics. In this sense, Lévinas regards the event as "beyond memory" - not historical memory but ethical memory. For Lévinas, it is a concept that lies beyond theologies of the past and beyond atheism. Such times, in which the traces of god are not heard in the world and religion's promises of a better future lose their meaning, actually require "the sovereignty of that primordial goodness or mercy that evil cannot overcome (a goodness uncovered in the turmoil...)." "39 Grossman preserves ethics through Ikonnikov, whom Lévinas describes as a "feebleminded" yet "inspired" man and "the son of a priest, but without theologically orthodox faith." As such, posits Lévinas, he is "perhaps the only character capable of expressing bold truths." 40

Using this model, and through the words of Ikonnikov, which he quotes at length, Lévinas further highlights the heavy ethical burden that at times falls on only one person. The task of preserving the idea of good and the ethical obligation of preserving ethicality in a world that has lost its ethics is not the product of higher education or the study of ethics in universities; rather, it stems from a personal readiness to bear this responsibility at a time and a place in which it has no witnesses and enjoys no support. The personal price of such readiness may be extremely high, as it is a journey into the storm. Lévinas reemerges from the world of literary and talmudic example and returns to the concrete instance under discussion: that of the teacher.

The significance of bearing this responsibility lies beyond our comprehension as it is aimed not at restoring a sense of certainty to the world but rather at restoring to the world the question. That is to say, the individual exercises ethical responsibility not through the emphatic declaration of good but by establishing the possibility of once again asking and enabling the good of the Other.

The ethical problem of a world that has lost all ethicality cannot be solved by the certain declaration of another set of ethics, as good competing with good is a struggle between two certainties. Good lies in the willingness to recognize the Other and in ethical responsibility toward the Other. This sheds additional light on the role of the teacher, who alone bears the immense responsibility for an entire world and, in this capacity, tries to stimulate good and cause others to awaken to it. The ethical choice presented by Lévinas is a fundamental choice of taking responsibility for responsibility.

38. Lévinas citing Grossman in "Beyond Memory," 91.

39. Lévinas "Beyond Memory," 90.

40. Ibid. 


\section{One Hundred And Twenty InTERpretations of LE'EMOR}

The concern with different aspects of speaking - the living and immobilized aspects of le dire and le dit-is a major element of Lévinas's meticulous philosophical inquiry. In many ways, the relationship between living speech - the "saying" - and speech that has already been articulated - the "said" - constitutes a central component of Lévinas's ethical doctrine. In this article, I focus on what Lévinas maintains he learned from Chouchani with regard to these aspects - that is, about the many possibilities of the saying, for which there are no less than one hundred and twenty interpretations. Lévinas considers the saying that enables the Other to speak, the saying that prevents the Other from speaking, the saying that bears responsibility for the responsibility of the Other, and the saying that closes off the Other and prevents him from taking responsibility.

The return of good and ethicality is revealed primarily in the display of respect toward the Other and others - not in the individual's certainty in himself. A world that has lost all good is a world to which good must be restored, not through the display of personal certainty but rather through a willingness for openness toward the Other and the responsibility that this openness involves. The deep meaning of education in the eye of the storm, explains Lévinas, lies not in the demonstration of certainty in the midst of a raging sea but rather in the willingness to live within the storm and to bear full responsibility for it, facilitating the existence of many other worlds from within the inner world of the individual. It is this notion that underlies the principle of the teacher who enables the student himself to play the role as a subject bearing responsibility. The goal of the teacher is not to say something, but rather to bring about an encounter between the student and the world around him that will enable him to say something. This is the power of Jewish teaching, maintains Lévinas, and refers the reader to a verse that appears numerous times in the Bible in different variations: "And the Lord said to Moses: "say to the people of Israel le'emor [in these terms]." This reference is made in the context of a lesson about the verse - which causes the reader to consider its meaning - conducted by $\mathrm{M}$. Chouchani. Seemingly, the verse is formulated incorrectly and contains an element of duplication, as Moses is asked to tell the Children of Israel the words of god that are being spoken to him. Nahmanides explains the first appearance of this verse in Exodus 6 as follows:

Commentators [a reference to Rabbi David Kimhi] have said that the word le'emor appears throughout the Torah to refer to God telling Moses to tell these things to the People of Israel... In my view, the word le'emor is used to reflect clarification of the issue on all levels-And God spoke to Moses with an absolute statement as opposed to an uncertain one, and not as a hint. This continues throughout the entire Torah, for Moses's prophecy is to be spoken face-to-face, clearly, and not in riddles (Numbers 12:8). ${ }^{41}$ 


\title{
Hanoch Ben-Pazi
}

Nahmanides offers two interpretations. The first appears to be comparable to the literal meaning of the word "saying," meaning that that which is said to Moses, Moses will say to the people of Israel. The second interpretation is a depiction of the statement, made in a manifest and open manner, as an absolute and conclusive statement. In addition to these two interpretations, which do not stray far from the biblical text, we can consider a list of other interpretations. Lévinas chooses to discuss this verse via a lesson on the subject, which he himself was taught by his teacher:

\begin{abstract}
A prestigious master I had after the Liberation used to claim to be able to give one hundred and twenty different interpretations of this phrase whose plain meaning, however, is devoid of mystery. He revealed only one to me. I have tried to guess a second. The one he revealed to me consisted in translating lemor by "so as not to say." Which amounted to signifying: "Say to the people of Israel so as not to say." The unspoken is necessary, so that listening remains a way of thinking; or it is necessary for the word to be also unspoken, so that truth (or the Word of God) does not consume those who listen; or the Word of God has to be able to lodge itself, without danger to mankind, in the tongue and language of men. In $\mathrm{m}$ own reading of this verse, lemor would signify "in order to say": "Say to the people of Israel in order for them to speak"; teach them sufficiently in depth for them to begin to speak, for them to hear at the point of speaking. ${ }^{42}$
\end{abstract}

Lévinas's two interpretations are strikingly consistent with the spirit of Moses's teaching as "slow of tongue." The wisdom of the teacher lies not in his ability to reveal but rather in his ability to refrain from revealing and to refrain from saying. The teacher's role is not to say what he was told so that the student may say what was told to him; his role, rather, is to not say, in a manner that enables the listener to say. The teacher's speech must be such that allows him to establish a presence within his listener, within his student, in a manner that enables the student to speak on his own. This description is similar to the above account of the "traces" that constitute the "past within the present" facing the still-unknown future. Lévinas's second interpretation is similar: the teacher should speak in a manner that enables the listener to speak.

But Lévinas adds another two sentences of particular interest, which hold great significance for both the student and the teacher: "The one hundred and eighteen other significations of the verse remain to be discovered. My master carried their secret to his tomb."43 That is to say, the teacher does not teach everything he knows; he keeps much knowledge to himself and does not articulate it to his student, thus teaching the student that he does not know everything and leaving him the role of discovering more and more new meanings that rely on the previous ones.

42. Emmanuel Lévinas, "The Pact," in Beyond the Verse, trans. Gary D. Mole (Bloomington: Indiana University Press, 1994), 80.

43. Ibid. 


\section{THREE TRUTHS}

We are now better equipped to return to the essay "Nameless" itself, and to consider the way in which the different elements that Lévinas attributes to his teacher find expression, in a unique texture, as truths that need to be learned in this era. Or to paraphrase Lévinas: What shall we teach our children beyond the story of the insanity and the illness of our memories? These elements can be formulated as three truths that an attentive ear can learn from the picturesque, sharp, and somewhat odd character of the great teacher M. Chouchani.

The first truth is that living a meaningful life in our world, and in the grand culture in which we live and are raising our children, requires much less than what we may think we need. According to Lévinas: "One can do without meals and rest, smiles and personal effects, decency and the right to turn the key to one's own room, pictures, friends, countrysides and sick leave...."44 In actuality, so many things that appear to be essential in our cultural world are actually dispensable. The ghetto is "not just separation away from the world," but also the deep understanding of what is required for a meaningful life from a human and ethical perspective. It is a return to the desert of sorts, to the space that cannot be measured in standard terms - only in inner terms; or, in the words of Lévinas, "to a space made to measure - like a tomb - to contain us." "45

The second truth pertains to the decisive and dramatic times that reveal the weakness of ethical values in preserving meaningful human existence. In such times, writes Lévinas, "the highest duty, when 'all is permitted,' consists in feeling oneself responsible with regard to these values of peace. ${ }^{46}$ We must not conclude based on times of crisis and times of war that qualities that are well suited for wartime are the only certainties, and that ethical life is ultimately a weakness. We must also not take pleasure in the "virile virtues" that characterize such tragic situations.

The third truth is the obligation to preserve and revive "the memory of those who, non-Jews and Jews, without even knowing or seeing one another, found a way to behave amidst total chaos as if the world had not fallen apart," and to remember "the resistance of the maquis, that is, precisely, a resistance having no other source but one's own certainty and inner-self." ${ }^{, 4}$

\section{Nonetheless, Maintains Lévinas, We Still Face a Crisis of Humanism}

For Lévinas, the human idea asserted by Jewish wisdom is neither religious nor national in character. It is the readiness to take responsibility for everything. The Jewish metaphor is the sukkah, the ritual booth that is open to the winds and that can be understood as symbolizing responsibility with no exterior support, ethics without institutional defense. To refer to this notion, Lévinas

44. Lévinas, "Nameless," 121.

45. Ibid. Also see above on the manner in which Lévinas employs the metaphor of the tomb with regard to Mr. Chouchani.

46. Lévinas, "Nameless," 121.

47. Ibid., 121-22. 


\section{Hanoch Ben-Pazi}

makes use of the talmudic expression of "the four cubits of the Halakhah."48 Its deep meaning is the imperative of preserving the feeble conscience in this broken world, to be focused on the internal state but to also simultaneously be oriented toward the outside world. This, I believe, is the ethical lesson that Lévinas learned from his teacher without a name_- "honor without a flag." And perhaps this is Lévinas's way of explaining the secret of his life and his fate.

$$
* * * * *
$$

This article made a case, albeit conjecturally, for understanding Lévinas's essay "Nameless" as a text devoted to a man without a name-M. Chouchani. On an ideological and philosophical level, Lévinas's essay does not tell the story of M. Chouchani and is not intended to publicly reveal his true name, his family affiliation or ethnic origin, or the educational home in which he grew up and developed. Rather, true to philosophical form, Lévinas offers a number of essential truths that can and should be learned from a teacher as virtuous as M. Chouchani. In retrospective view, the main points of this essay have the capacity to recount the great philosophical and ethical story that Lévinas attempts to tell based on the inspiration of the image and teachings of M. Chouchani.

The first principle is the teacher's willingness to enter into the eye of the ethical storm in the world - not to remain outside, maintaining his conduct as "a human being" and waiting for the winds of evil to pass from the world, as if "in the tempest rest resided," according to Lermontov, as quoted by Lévinas. The second principle is the absence of eloquence, not as something that is marginal to teaching but as a central element - the choice of refraining from using the tools of rhetoric and pleasant formulations to draw a large and clear picture, out of respect for the text and the individual and in order to enable the critical questions to be asked, even if they appear unaccompanied by answers. The third principle is the willingness to bear responsibility, even in the context of great and infinite isolation; meaning, the individual's capacity to observe that humanity has lost its way and lost its mind, and his willingness to go it alone in bearing responsibility for the entire world. The fourth principle is the journey-that is, to be forever ready to set out on a journey and to regard teaching and education as a "tent of assembly" and a place of study that, at any given moment, can be packed up and carried on our backs in order to embark on a new path. The fifth principle is memory and that which lies beyond memory. The ability to remember is not simply an attribute or a natural-born skill that people must cultivate. Rather, memory, and responsibility for that which lies beyond memory, is an ethical question of the individual whose shoulders bear the ethical significance of knowledge, thought, and the Torah. And this brings us to the sixth principle of teaching: the student's responsibility to teach others and the reading of the obvious verse that has thus far appeared to be self-evident, as if it lacks all meaning, or, more precisely, has so many meanings - the other hundred of which, Lévinas tells us, were taken by his teacher to the grave. 
This inquiry enables us to view the figure of M. Chouchani not only via the principles and the methods of instruction we stand to learn from him but as someone who reflects, in the most internal and external ways possible, what Lévinas refers to as the "Jewish condition."

In the most profound sense, says Lévinas, it is the great responsibility of safeguarding the values of peace in a world in a state of war, and for preserving internal ethical life in a world whose exterior is devoid of all ethicality, that gives meaning to the Jewish assertion that, since the destruction of the temple, we have only the "four cubits of the Halakhah." In other words, when the "shelter of conscience" is "exposed to all the winds" and when the flags of good are not flying at full mast, the individual has no other recourse but to justify himself "in the fragility of conscience, in the 'four cubits of the Halakhah,' in that precarious, divine abode." $" 49$

This, according to Lévinas, is the "Jewish condition" of humanness and the hero who finds rest in the eye of the storm. It may also be one of the most important educational and ethical lessons that we stand to learn from Lévinas's "Nameless" essay, from his collection of essays dedicated to Proper Names.

Hanoch Ben-Pazi Bar-Ilan University 